\title{
IOMTARA (INTERIOR OMAH NUSANTARA) : APLIKASI ROOM TOUR DENGAN MENGGUNAKAN TEKNOLOGI VIRTUAL REALITY SEBAGAI MEDIA PENGENALAN PARIWISATA RUMAH TRADISIONAL NUSANTARA
}

\author{
Swastika Dhesti Anggriani ${ }^{1}$, Lisa Sidyawati ${ }^{2}$, Ponimin ${ }^{3}$, Norsidah Ujang ${ }^{4}$ \\ ${ }^{1}$ Email: swastikadhesti.fs@um.ac.id \\ Fakultas Sastra, Universitas Negeri Malang \\ 2Email: lisa.sidyawati.fs@um.ac.id \\ Fakultas Sastra, Universitas Negeri Malang \\ ${ }^{3}$ Email: ponimin.fs@um.ac.id \\ Fakultas Sastra, Universitas Negeri Malang \\ ${ }^{\$}$ Email: norsidah@upm.edu.my \\ Faculty of Design and Architecture, Universiti Putra Malaysia
}

\begin{abstract}
The role of information technology is the main thing that must be fulfilled to support activities in various fields of life, including the promotion of tourism. One of the developing information is Virtual Reality technology. iOMTARA (interior of Omah Nusantara) is a room tour application development that was created as a media for the introduction and promotion of tourism in the Nusantara. The 3D objects displayed in this application are Joglo Yogyakarta Indonesia's traditional house and Melaka Malaysia's traditional house. Both of them were chosen because currently the traditional house no longer functions as a residence but also as a tourist attraction for both foreign and domestic tourists. This application was developed using interactive visual methods such as virtual worlds that make users feel like they are getting the same information as the experience of entering the space in the real houses. The application of building 3D objects from houses is followed by making video interactions using virtual reality. The final stage, this application will be incorporated into a mobile phone based on the Android operating system so that it can be used easily by the people. The application design method begins with a preliminary study of qualitative methods to obtain data directly in the field. Then the data is used to designing virtual reality in the IOMTARA Room Tour application. The result of making this application is the design of an iOMTARA application that uses Virtual Reality technology and can be used on mobile phone based on the Android system. It is expected that with this application, the people is more familiar with tourism objects in the Nusantara, especially the Joglo Yogyakarta Indonesia's traditional house and the Melaka Malaysia's traditional house.
\end{abstract}

\begin{abstract}
Abstrak: Peranan teknologi informasi, saat ini menjadi hal utama yang harus dipenuhi untuk menunjang kegiatan dalam berbagai bidang kehidupan, tidak terkecuali bidang promosi pariwisata. Salah satu teknologi informasi yang berkembang adalah teknologi virtual reality. iOMTARA (interior Omah Nusantara) adalah sebuah pengembangan aplikasi room tour yang dibuat sebagai media pengenalan dan promosi pariwisata di Nusantara. Objek 3D yang ditampilkan pada aplikasi ini adalah rumah tradisional Joglo Yogyakarta Indonesia dan rumah tradisional Melaka Malaysia. Kedua rumah tersebut dipilih karena saat ini rumah tradisional tidak lagi berfungsi sebagai rumah tinggal tetapi juga sebagai objek wisata baik bagi wisatawan asing maupun domestik. Aplikasi ini dikembangkan menggunakan metode visual yang interaktif seperti dunia virtual yang membuat penggunanya seolah-olah memperoleh informasi yang sama seperti pengalaman memasuki ruang tersebut pada dunia nyata. Aplikasi bangunan objek 3D dari rumah yang kemudian dilanjutkan dengan pembuatan interaksi berupa video menggunakan virtual reality. Tahap akhir, aplikasi ini akan dimasukkan ke dalam mobile phone yang berbasis sistem operasi android sehingga dapat digunakan dengan mudah oleh masyarakat umum. Metode perancangan aplikasi diawali dengan penelitian awal metode kualitatif untuk memperoleh data secara langsung di lapangan. Selanjutnya data tersebut digunakan untuk merancang virtual reality pada aplikasi room tour IOMTARA. Hasil dari pembuatan aplikasi ini adalah terancangnya sebuah aplikasi iOMTARA yang menggunakan teknologi virtual reality dan dapat digunakan pada mobile phone yang berbasis sistem android. Diharapkan dengan adanya aplikasi ini, masyarakat umum lebih mengenal tentang objek pariwisata di
\end{abstract}


Nusantara, khususnya rumah tradisional Joglo Yogyakarta Indonesia dan rumah tradisional Melaka Malaysia.

Keywords: virtual aplication, virtual reality, joglo, melaka, android.

\section{PENDAHULUAN}

Perkembangan teknologi yang terjadi dalam waktu relatif cepat saat ini tidak dapat dipungkiri sangat besar manfaatnya bagi kehidupan manusia. Salah satu teknologi yang berkembang tersebut adalah sistem informasi yang ditampilkan dalam bentuk 3D (tiga dimensi). Dahulu, sistem informasi disampaikan melalui teknologi 2D (dua dimensi) dimana informasi akan disampaikan dalam bentuk gambar, poster, iklan, dan foto sehingga seringkali informasi yang disampaikan menjadi kurang mendalam. Setelah era 2D terlewati, saat ini informasi mulai disampaikan menggunakan teknologi 3D, dimana informasi akan disampaikan dalam bentuk visual benda atau objek yang mengikuti bentuk aslinya. Salah satu inovasi 3D dalam bidang informasi saat ini adalah virtual reality. Virtual reality (VR) atau realitas maya adalah teknologi yang membuat pengguna dapat berinteraksi dengan suatu lingkungan yang disimulasikan oleh komputer (computer simulated environtment). Lingkungan yang disimulasikan oleh komputer dapat berupa suatu lingkungan sebenarnya yang ditiru atau lingkungan yang tidak nyata/ imajinasi (Sihite, Samopa, dan Sani, 2013: A397). Sederhananya, virtual reality adalah permunculan gambar-gambar atau model 3D yang dibangkitkan oleh komputer dan terlihat nyata dengan bantuan sejumlah peralatan tertentu (Paoluzzi dalam Prasetyo, Satoto, dan Martono, 2015: 134). Salah satu peralatan yang membantu pengoperasian teknologi Virtual Reality ini adalah headset VR yang berbentuk seperti kacamata selam, namun dengan lensa tertutup. Peralatan ini disebut dengan $V R$ box, yang merupakan tempat untuk meletakkan mobile phone atau smartphone yang berfungsi memproyeksikan gambar virtual (Solicitor, Noventius, dan Bayu, 2018).

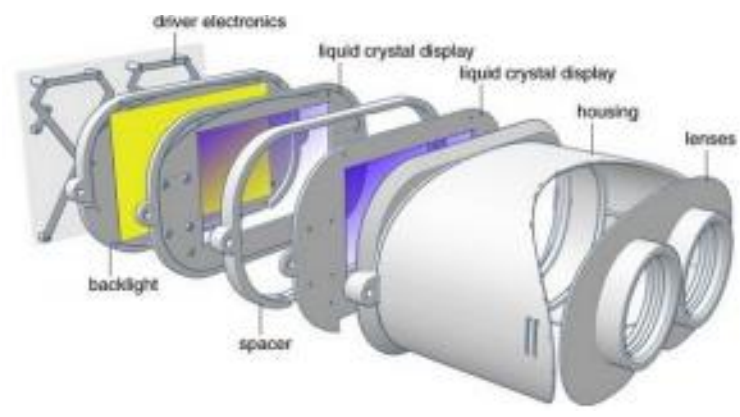

Gambar 1. Susunan Komponen pada Perangkat Headset VR

Sumber: Solicitor, Noventius, Bayu, 2018

iOMTARA atau interior Omah Nusantara adalah sebuah aplikasi room tour yang dikembangkan dengan menggunakan teknologi virtual reality. Di dalam aplikasi ini akan ditampilkan objek 3D yaitu rumah tradisional Joglo Yogyakarta Indonesia dan rumah tradisional Melaka Malaysia. Objek dibuat secara virtual tetapi tetap memperhitungkan sifat-sifat fisiknya. Aplikasi yang dibangun akan menggunakan gambar bangunan untuk pembuatan objek berbentuk 3D kemudian dilanjutkan dengan pembuatan interaksi berupa video dan animasi menmenggunakan Virtual Reality. Tahap akhirnya dimasukkan kedalam mobile phone yang berbasis sistem operasi android.

Rumah tradisional saat ini bukan lagi berfungsi sebagai rumah tinggal tetapi juga merupakan objek wisata yang banyak dikunjungi oleh wisatawan, baik wisatawan asing maupun domestik. Seperti rumah tradisional Joglo yang terdapat di DI. Yogyakarta, Indonesia. Rumah Joglo tidak hanya berfungsi sebagai tempat tinggal, tetapi juga sebagai objek wisata, lokasi pengambilan gambar atau video untuk promosi pariwisata, serta objek penelitian. Di Malaysia, rumah tradisional Melaka juga menjadi objek wisata yang ramai dikunjungi oleh wisatawan. Salah satu tujuan wisata rumah tradisional yang cukup dikenal di Malaysia adalah Kampung Morten yang merupakan kampung wisata rumah tradisional Melaka.

Joglo merupakan bangunan yang khas dengan fungsi setiap bagian atau ruangnya yang berbeda satu dengan lainnya serta mengandung unsur filosofis yang sarat dengan nilai-nilai religi, kepercayaan, norma, dan nilai budaya Jawa. Selain itu, Joglo juga memiliki makna historis yang perlu dipelihara (Djono, Utomo, dan Subiyantoro, 2012). Rumah Joglo secara mendasar merupakan manifestasi pandangan hidup orang jawa yang mnekankan nilai keharmonisan dan kesatuan dua dunia yang berbeda sebagaimana laki-laki dan perempuan, fisik dan spiritual, isi dan wadhag, makrokosmos dan mikrokosmos (Slamet Subiyantoro, 2010). 
Susunan ruang pada rumah tinggal tradisional Joglo sesuai dengan klasifikasi pola ruang dalam yang terdiri dari 4 buah jenis ruang yaitu dalem, pawon, pekiwan, dan sisir. Penggunaan atap joglo pada rumah adat Kudus menunjukkan tingkat ekonomi sosial pemiliknya, misalnya haji, saudagar, atau juragan (Rasyidi, 2017).

Pada rumah tradisional Melaka, dijelaskan bahwa rumah melayu bukan saja sebagai tempat tinggal dan beraktivitas, tetapi juga menjadi lambang kesempurnaan hidup orang melayu. Ciri-ciri rumah tradisional Melayu bukan saja pada bagian-bagian rumah tetapi juga pada upacara, bahan, nama, dan kedudukan rumah itu. Bentuk rumah tradisional Melayu ditentukan oleh bentuk atapnya. Selain itu di dalam rumah tradisional Melayu terdapat beberapa jenis tiang dengan nama dan fungsi tertentu (Aziz, Jahi, Arifin, dan Ujang, 2014). Hubungan antara budaya, kepercayaan, dan aspek lingkungan dari iklim tropis nusantara berpengaruh besar dalam membentuk karakter unik dari Rumah Melaka Malaysia sebagai aset budaya yang penting dan tidak akan bisa ditemukan di belahan dunia lainnya (Talib dan Sulieman (2012)

Berdasarkan penjelasan tersebut, baik rumah tradisional Joglo di Yogyakarta Indonesia dan rumah tradisional Melaka di Malaysia, keduanya memiliki ciri khas yang ditonjolkan sebagai salah satu tujuan pariwisata Nusantara. Akan tetapi, tidak semua masyarakat dapat langsung datang ke masing-masing rumah tradisional tersebut, sehingga dibutuhkan media yang dapat menjadi sarana bagi masyarakat untuk mendapatkan pengalaman ruang yang sama seperti ketika masuk ke kedua rumah tersebut. Aplikasi iOMTARA yang dikembangkan dengan teknologi Virtual Reality diharapkan dapat menjadi media pengenalan kedua objek pariwisata Nusantara tersebut.

\section{METODE PENELITIAN}

Metode yang digunakan pada perancangan dan pembuatan aplikasi iOMTARA ini adalah metode kualitatif untuk mendapatkan informasi yang mendalam tentang rumah tradisional Joglo Yogyakarta Indonesia dan rumah tradisional Melaka Malaysia. Penelitian kualitatif adalah penelitian yang bermaksud untuk memahami fenomena tentang apa yang dialami oleh subjek penelitian misalnya perilaku, persepsi, motivasi, dan tindakan. Metode penelitian kualitatif sering disebut metode penelitian naturalistik karena penelitiannya dilakukan pada kondisi yang alamiah atau natural setting (Sugiyono, 2011: 8). Berdasarkan data hasil pengumpulan di lapangan, selanjutnya digunakan untuk merancang aplikasi iOMTARA yang menggunakan teknologi virtual reality. Melalui pendekatan kualitatif tersebut, diharapkan data yang diperoleh dapat sesuai dan terperinci untuk menunjang pembuatan aplikasi.

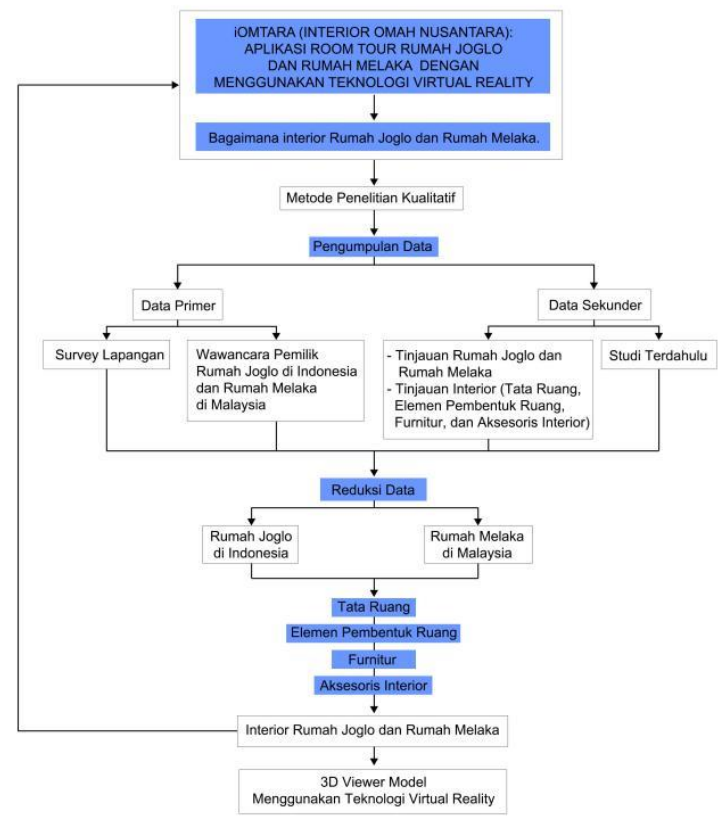

Gambar 2. Metode Penelitian

Di dalam metode penelitian kualitatif, data yang harus dikumpulkan meliputi data primer dan data sekunder. Data primer adalah data dalam bentuk verbal yang diucapkan secara lisan, gerak-gerik, atau perilaku subjek yang berkaitan dengan penelitian, sedangkan data sekunder adalah data yang diperoleh dari dokumen, foto, gambar, dan benda lain yang mendukung data primer (Arikunto, 2010: 21-22). Pada penelitian rumah tradisional Joglo dan rumah tradisional Melaka data primer diperoleh dari peghuni dan masyarakat sekitar rumah, sedangkan data sekunder diperoleh dari bangunan rumah. Hasilnya akan dianalisis untuk mendapatkan jawaban rumusan masalah dan kemudian data disajikan dalam bentuk dekripsi.

\section{Penentuan Sumber Data}

Sumber data dalam penelitian adalah subjek darimana data diperoleh. Apabila peneliti menggunakan teknik observasi, maka sumber datanya berupa benda (Sugiyono, 2011: 172). Di dalam penelitian ini sumber datanya adalah rumah tradisional Joglo di Yogyakarta, Indonesia dan rumah tradisional Melaka di Melaka, Malaysia.

\section{Metode Pengumpulan Data}


Teknik pengumpulan data yang utama digunakan pada penelitian adalah observasi lapangan, wawancara, dokumentasi, dan gabungan ketiganya (triangulasi).

\section{Observasi Lapangan}

Pada metode ini peneliti langsung datang ke lokasi penelitian yaitu rumah tradisional Joglo dan rumah tradisional Melaka untuk mengetahui kondisi rumah, serta mendapatkan data primer dan sekunder dari objek penelitian.

\section{Wawancara}

Wawancara dilakukan oleh peneliti pada narasumber yaitu penghuni rumah, masyarakat sekitar, dan orang-orang yang memahami perkembangan rumah tradisional Joglo dan rumah tradisional Melaka. Wawancara dilaksanakan secara tidak terstruktur, dimana peneliti hanya menggunakan pedoman berupa garis besar permasalahan yang akan ditanyakan (Sugiyono, 2011: 233-234). Hasil yang diperoleh berupa data dalam bentuk verbal yaitu rekaman hasil wawancara, catatan hasil wawancara, dan data pendukung lainnya yang bisa menjadi data sekunder seperti foto dan gambar.

\section{Dokumentasi}

Hasil dokumentasi pengumpulan data berupa data arsitektur dan interior seperti denah, gambar tampak, serta potongan. Selain itu data dokumentasi juga berupa foto-foto dan gambar yang berkaitan dengan objek penelitian.

\section{Triangulasi}

Triangulasi diartikan sebagai teknik pengumpulan data yang bersifat menggabungkan dari berbagai teknik pengumpulan data dan sumber data yang telah ada. Peneliti menggunakan teknik pengumpulan data observasi, wawancara, dan dokumentasi dari sumber data yang sama (Sugiyono, 2011: 233-241) pada waktu bersamaan di lokasi penelitian.

\section{Metode Analisis Data}

Teknik analisis data yang digunakan pada penelitian tentang rumah tradisional Joglo dan rumah tradisional Melaka adalah analisis sebelum datang ke lapangan, dan analisis secara bersamaan dengan pengumpulan data di lapangan.

\section{Analisis Sebelum di Lapangan}

Analisis sebelum di lapangan dilakukan terhadap data hasil studi pendahuluan, atau data sekunder yang akan digunakan untuk menentukan fokus penelitian (Sugiyono, 2011: 245). Fokus penelitian masih bersifat sementara, dan akan berkembang setelah peneliti masuk dan selama di lapangan.

\section{Analisis Data di Lapangan Model Miles dan Huberman}

Miles dan Huberman mengemukakan bahwa aktivitas dalam analisis data yaitu reduksi data, penyajian data, serta penarikan kesimpulan dan verifikasi.

Mereduksi data berarti merangkum, memilih hal-hal yang pokok, memfokuskan pada hal-hal yang penting, serta mencari tema dan pola. Reduksi data dapat dibantu dengan peralatan elektronik seperti komputer dengan memberikan kode pada aspek-aspek tertentu (Sugiyono, 2011: 247). Data yang direduksi yaitu interior Rumah Joglo dan Rmah Melaka.

\section{HASIL DAN PEMBAHASAN}

Berdasarkan hasil studi pustaka, observasi, wawancara, dokumentasi, dan analisis yang dilakukan, dapat disimpulkan bahwa:

1. Baik rumah tradisional Joglo di Yogyakarta maupun rumah tradisional Melaka di Malaysia, belum memiliki media pengenalan dalam bentuk teknologi 3D atau virtual reality. Media pengenalan yang sudah ada berupa gambar/ foto $2 \mathrm{D}$ yang tercantum pada brosur dinilai belum memberikan gambaran yang cukup tentang rumah tradisional tersebut.

2. Masyarakat tidak membaca dengan teliti ketika diberi brosur atau buku yang menampilkan gambar 2D. Selain itu, masyarakat juga cenderung lebih tertarik ketika diberi gambar dalam bentuk 3D yang memanfaatkan teknologi seperti virtual reality dan dapat digunakan pada mobile phone miliknya sendiri.

3. Biaya yang mahal jika harus berkunjung ke objek wisata langsung, sehingga tidak semua orang tertarik untuk datang terus menerus atau berulang kali untuk melihat objek wisata tersebut.

\section{Rumah Tradisional Joglo Yogyakarta Indonesia}

Rumah tradisional Joglo yang digunakan sebagai objek berada di Kabupaten Bantul, DI. Yogyakarta, Indonesia. Rumah ini merupakan salah satu Rumah Tradisional Joglo yang masih dilestarikan dan memiliki susunan ruang yang lengkap. Rumah Joglo ini sampai saat ini masih difungsikan sebagai rumah tinggal oleh keluarga 
pendiri rumah. Sebagai salah satu Rumah Joglo yang memiliki susunan ruang lengkap, rumah ini juga seringkali dikunjungi oleh wisatawan baik dari Indonesia maupun Internasional untuk melihat hasil kearifan lokal Nusantara. Selain itu, rumah ini juga seringkali digunakan sebagai latar lokasi pengambilan gambar film nasional yang mengambil tema Jawa.

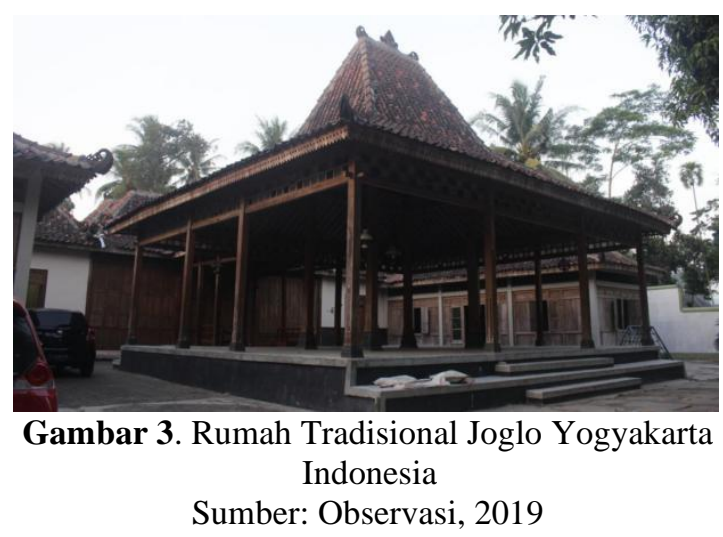

Joglo merupakan bangunan yang khas dengan fungsi setiap bagian atau ruangnya yang berbeda satu dengan lainnya serta mengandung unsur filosofis yang sarat dengan nilai-nilai religi, kepercayaan, norma, dan nilai budaya Jawa. Selain itu, Joglo juga memiliki makna historis yang perlu dipelihara (Djono, Utomo, dan Subiyantoro, 2012). Rumah Joglo secara mendasar merupakan manifestasi pandangan hidup orang jawa yang mnekankan nilai keharmonisan dan kesatuan dua dunia yang berbeda sebagaimana laki-laki dan perempuan, fisik dan spiritual, isi dan wadhag, makrokosmos dan mikrokosmos (Slamet Subiyantoro, 2010). Susunan ruang pada rumah tinggal tradisional Joglo sesuai dengan klasifikasi pola ruang dalam yang terdiri dari 4 buah jenis ruang yaitu dalem, pawon, pekiwan, dan sisir. Penggunaan atap joglo pada rumah adat Kudus menunjukkan tingkat ekonomi sosial pemiliknya, misalnya haji, saudagar, atau juragan (Rasyidi, 2017).

\section{Rumah Tradisional Melaka Malaysia}

Rumah tradisional Melaka yang dijadikan objek berada di Mini Malaysia dan Kampung Morten, Melaka, Malaysia. Mini Malaysia merupakan salah satu tempat wisata di Melaka yang menampilkan semua jenis rumah tradisional Malaysia. Akan tetapi di tempat ini, rumah tidak difungsikan sebagai rumah tinggal lagi, melainkan hanya sebagai museum. Rumah kedua berada di Kampung Morten, Melaka, Malaysia yang juga merupakan sebuah kampung wisata yang cukup dikenal. Rumah tradisional Melaka di tempat ini masih digunakan dan difungsikan sebagai rumah tinggal oleh pemilik rumah. Sampel ini dipilih untuk melihat furnitur, aksesoris, dan fungsi ruang saat ini.

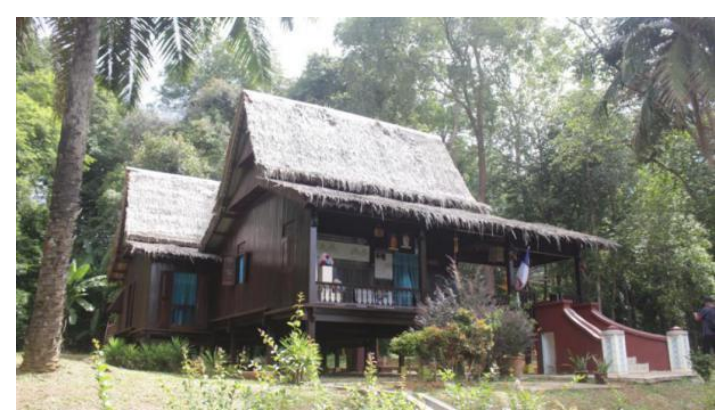

Gambar 4. Rumah Tradisional Melaka Malaysia Sumber: Observasi, 2019

Pada rumah tradisional Melaka, dijelaskan bahwa konsep dan ruang memegang peranan penting. Konsep ruang Rumah Melaka dipisahkan menjadi 3 bagian seperti rumah ibu, dapur, dan bagian depan rumah untuk menerima tamu (Noor Shahira Abu Bakar, dkk., 2013). Rumah melayu bukan saja sebagai tempat tinggal dan beraktivitas, tetapi juga menjadi lambang kesempurnaan hidup orang melayu. Ciri-ciri rumah tradisional Melayu bukan saja pada bagian-bagian rumah tetapi juga pada upacara, bahan, nama, dan kedudukan rumah itu. Bentuk rumah tradisional Melayu ditentukan oleh bentuk atapnya. Selain itu di dalam rumah tradisional Melayu terdapat beberapa jenis tiang dengan nama dan fungsi tertentu (Aziz, Jahi, Arifin, dan Ujang, 2014). Hubungan antara budaya, kepercayaan, dan aspek lingkungan dari iklim tropis nusantara berpengaruh besar dalam membentuk karakter unik dari Rumah Melaka Malaysia sebagai aset budaya yang penting dan tidak akan bisa ditemukan di belahan dunia lainnya (Talib dan Sulieman (2012)

\section{Konsep Perancangan iOMTARA}

Pada perancangan iOMTARA, digunakan konsep Discovery Experience of Traditional House yang lebih menonjolkan suasana jelajah rumah. Dimulai dari bagian luar rumah, dimana pengguna dapat melihat bangunan tampak luar rumah baik dari tampak depan, samping, maupun belakang rumah. Kemudian pengguna dapat masuk ke dalam rumah melalui pintu depan yang otomatis akan terbuka ketika pengguna berjalan ke arah pintu dan kursor diarahkan menyorot ke pintu. Pengguna dapat masuk ke dalam seluruh 
ruangan rumah dan melihat furnitur yang ada di dalamnya.

Tampilan visual dibuat dengan bentuk 3D agar lebih menarik dan seolah-olah seperti berada di ruangan aslinya. Konsep Discovery Experience lebih menonjolkan penggunaan objek-objek yang sesuai dengan lingkungan aslinya, seperti bentuk rumah, bentuk pintu dan jendela, bentuk furnitur, dan warna material. Diharapkan pengguna dapat merasakan sebuah pengalaman ruang seperti sedang berkunjung ke rumah aslinya.

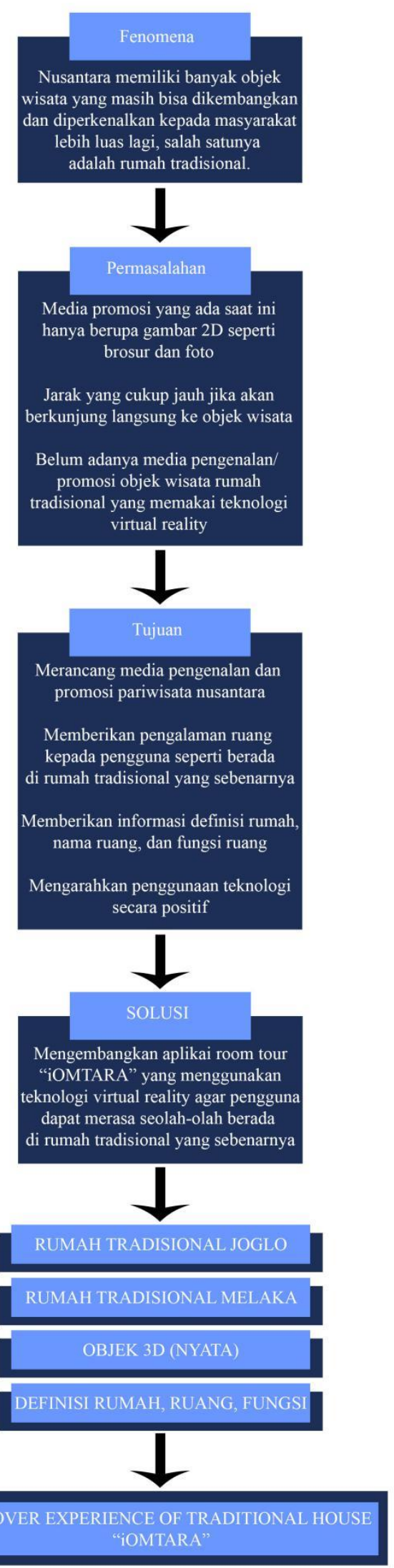

Gambar 5. Diagram Konsep Perancangan iOMTARA Sumber: Penulis, 2019

\section{Studi Bentuk}


Bentuk visualisasi rumah dan furnitur menggunakan permodelan tiga dimensi (3D) atau dikenal juga dengan 3D modelling adalah proses pembuatan representasi matematis permukaan 3D dari suatu objek dengan software tertentu. Produk hasil permodelan tersebut disebut model 3D. Model 3D dapat ditampilkan sebagai citra 2 dimensi melalui sebuah proses rendering (Solicitor, Noventinus, \& Bayu, 2018).
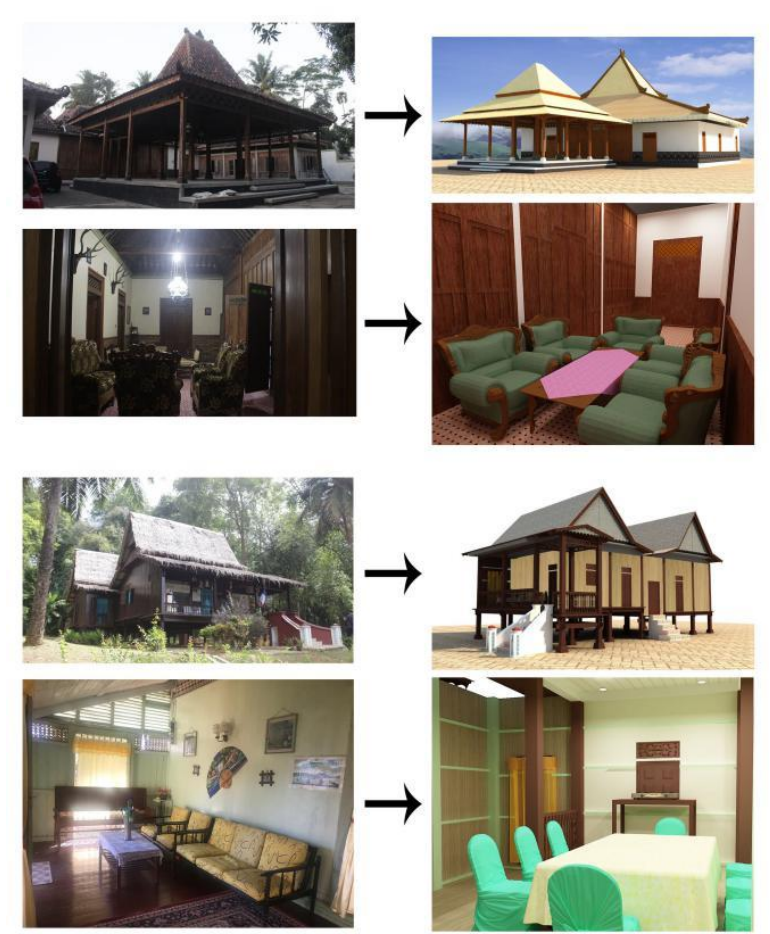

Gambar 6. Studi Bentuk Perancangan iOMTARA Sumber: Penulis, 2019

Visualisasi bentuk rumah dibuat berdasarkan acuan bentuk rumah aslinya. Bentuk rumah tradisional Joglo Yogyakarta dibuat dengan mengambil bentuk, ukuran, tatanan, warna, dan material yang mengacu pada rumah Joglo hasil observasi yang ada di Yogyakarta. Selain itu, furnitur yang ditempatkan di dalam rumah tradisional Joglo juga dibuat hampir sama dengan furnitur asli yang terdapat di dalam rumah.

Sama seperti rumah tradisional Joglo Yogyakarta, rumah tradisional Melaka Malaysia juga dibuat dengan acuan bentuk rumah asli yang diperloleh dari hasil observasi langsung. Bentuk rumah, ukuran, warna, dan material dibuat sesuai dengan bentuk aslinya di rumah tradisional Melaka yang ada di Malaysia. Furnitur dan perlengkapan di dalam rumah juga dibuat semirip mungkin dengan furnitur sebenarnya yang ada di dalam rumah.

\section{Struktur Navigasi}

Gambaran tampak luar rumah dan bagian dalam rumah (ruang) pada aplikasi dibuat dengan mengikuti sirkulasi asli pada denah rumah tradisional joglo dan rumah tradisional melaka. Di dalam denah terdapat 2 tipe objek yang berberan penting dalam sistem yaitu objek pengguna dan objek rumah, ruang, beserta furnitur di dalamnya. Objek pengguna diberi sistem pergerakan translasi otomatis yang mengelilingi seluruh wilayah luar rumah dan ruang dalam. Tujuan dari pergerakan otomatis tersebut berfungsi untuk memberikan pengalaman menggunakan ruang kepada pengguna, sedangkan objek rumah, ruang, dan furnitur akan tetap diam sehingga mudah diobservasi untuk keperluan informasi.

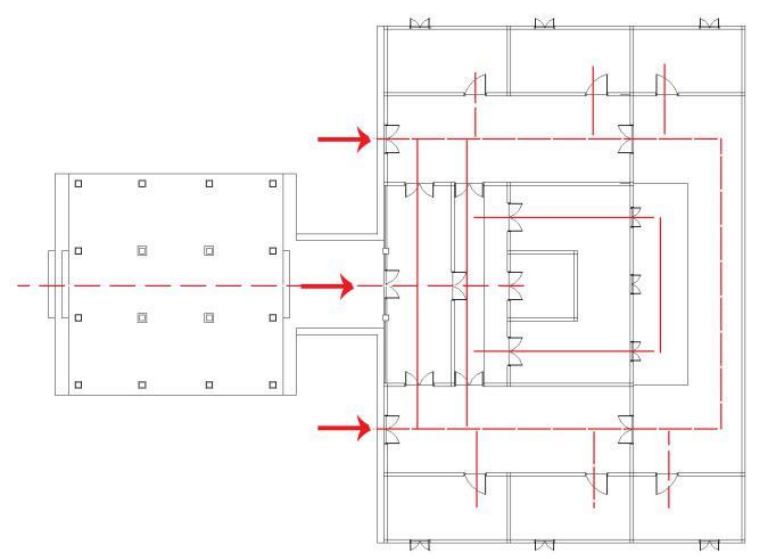

Gambar 7. Denah Navigasi Rumah Tradisional Joglo Yogyakarta

Sumber: Penulis, 2019

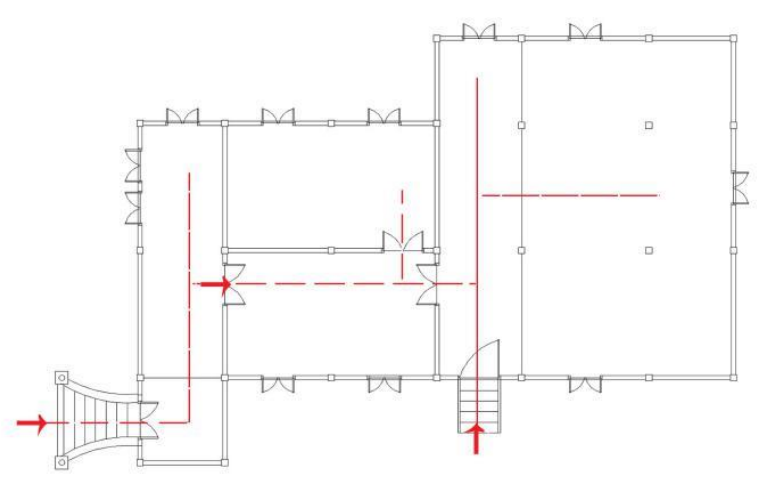

Gambar 8. Denah Navigasi Rumah Tradisional Melaka Malaysia

Sumber: Penulis, 2019

Setelah keseluruhan tampilan denah dikerjakan, selanjutnya membuat struktur navigasi pada VR. Struktur navigasi ini merupakan alur dari suatu aplikasi yang merupakan rancangan hubungan atau rantai kerja dari beberapa area berbeda. Navigasi ini adapat membantu 
mengorganisasikan seluruh elemen pembuatan virtual reality. Struktur navigasi yang digunakan pada aplikasi ini adalah struktur navigasin linier yang hanya mempunyai 1 rangkaian cerita berurutan yang menampilkan satu per satu tampilan layar secara berurutan.

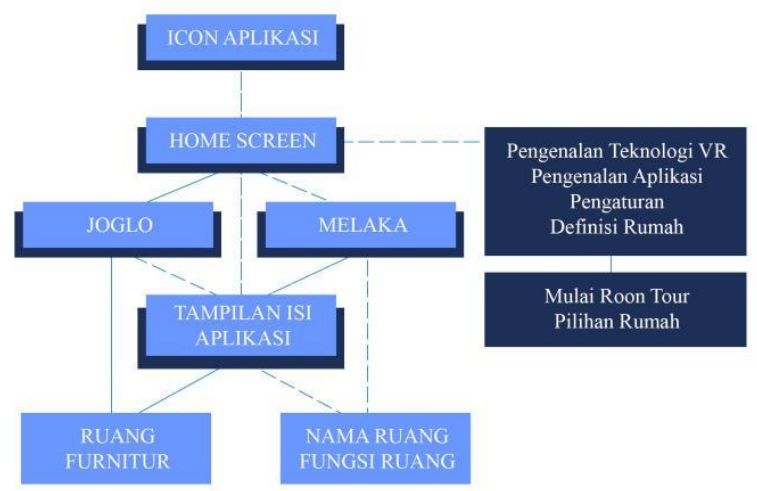

Gambar 9. Struktur Navigasi Sumber: Penulis, 2019

\section{Visual Elemen Aplication}

Logo aplikasi adalah salah satu elemen visual yang digunakan untuk membuka aplikasi. iOMTARA merupakan nama dan logo aplikasi yang merupakan singkatan dari "interior Omah Nusantara". Logo dibuat sederhana dengan mengambil bentukan menyerupai atap rumah yang meruncing keatas. Warna dari logo ini menggunakan warna netral yaitu biru agar tidak mendominasi label utama iOMTARA.

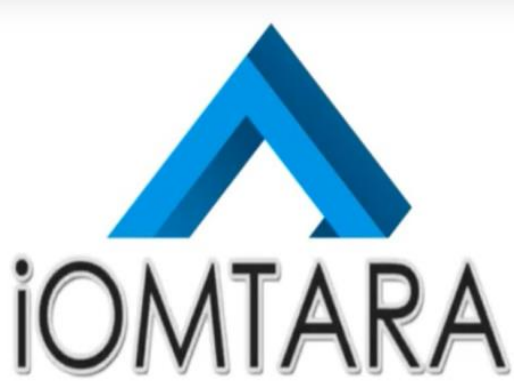

Gambar 10. Logo iOMTARA

Selain logo, ikon aplikasi juga merupakan salah satu visual yang penting untuk membuka aplikasi. Pada aplikasi ini, ikon menggunakan salah satu gambar 2D rumah tradisional, yaitu rumah tradisional Joglo Yogyakarta.
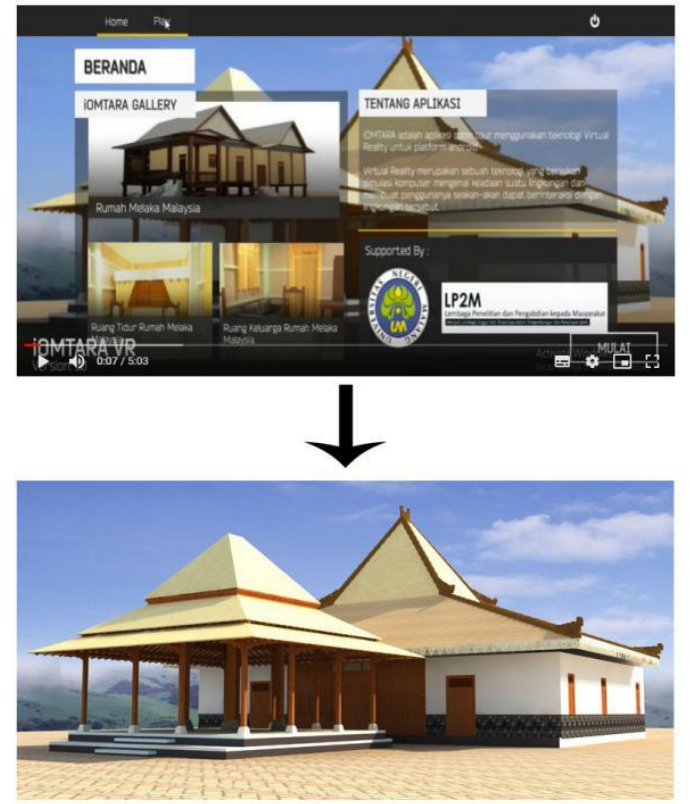

Gambar 11. Ikon iOMTARA

Bagian elemen visual lain yang harus ada adalah tombol atau button. Tombol berfungsi sebagai media interaksi agar pengguna dapat memanfaatkan fasilitas yang ada di dalam aplikasi. Setiap tombol memiliki fungsinya masing-masing, seperti:

- Tombol play, berfungsi untuk memulai aplikasi ketika berada di tampilan awal (homel beranda). Tombol ini juga berfungsi untuk memulai dengan memilih tampilan rumah mana yang akan dijalankan fungsi room tour nya.

- Tombol home, berfungsi untuk kembali ke menu utama dan memilih melanjutkan room tour ke rumah lainnya.

- Tombol keterangan, berfungsi untuk melihat keterangan/ identitas rumah dan ruangan

- Tombol panel, berfungsi untuk melihat keterangan fungsi ruang.

- Tombol on/off, bergungsi untuk mengaktifan menonaktifkan aplikasi di mobile phone.

\section{Tampilan Aplikasi iOMTARA}

Seperti yang telah dijabarkan sebelumnya, tampilan aplikasi iOMTARA dibagi menjadi beberapa bagian, dimulai dari tampilan pembuka, beranda, pilihan ruang, ruangan, dan panel tambahan. 


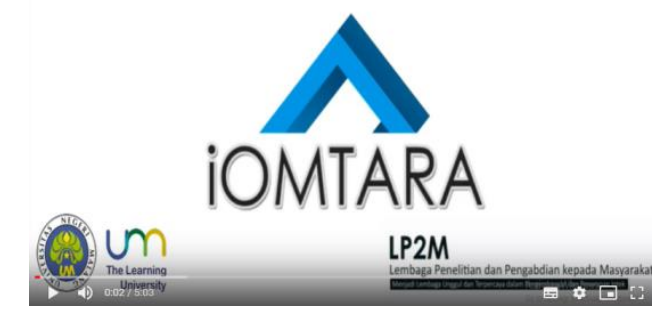

Gambar 12. Tampilan Awal Aplikasi iOMTARA

Aplikasi diawali dengan ditampilkannya logo dan ikon aplikasi iOMTARA. Pada tampilan awal ini, belum diberikan informasi atau keterangan apapun tentang aplikasi. Selanjutnya, pengguna harus menunggu beberapa detik untuk melanjutkan masuk ke beranda.

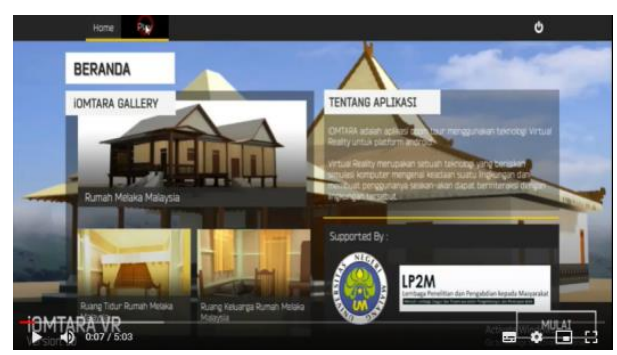

Gambar 13. Beranda Aplikasi iOMTARA

Pada beranda, diberikan tampilan keterangan tentang aplikasi. Selain itu diberikan juga gambaran awal berupa galeri gambar 2D dari masing-masing rumah tradisional. Pengguna dapat memilih untuk melihat tampilan galeri gambar 2D atau dapat juga langsung memulai aplikasi virtual reality.

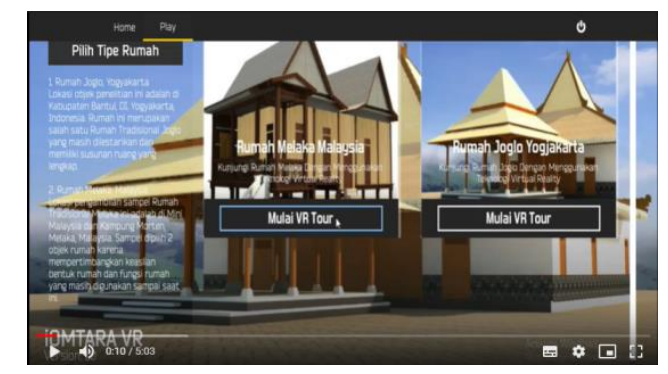

Gambar 14. Pilihan Tipe Rumah pada Aplikasi iOMTARA

Setelah memilih tombol 'mulai', pengguna akan diarahkan menuju halaman dimana terdapat pilihan tipe rumah tradisional Joglo dan rumah tradisional Melaka. Pengguna dapat memilih tipe rumah dan memulai VR Tour. Pada bagian ini juga, pengguna diberikan tampilan deskripsi masing-masing rumah.

Tabel 1. Tampilan Panel Aplikasi iOMTARA tipe rumah tradisional Joglo

\begin{tabular}{|c|c|c|}
\hline No & Tampilan Panel & Keterangan \\
\hline 1. & 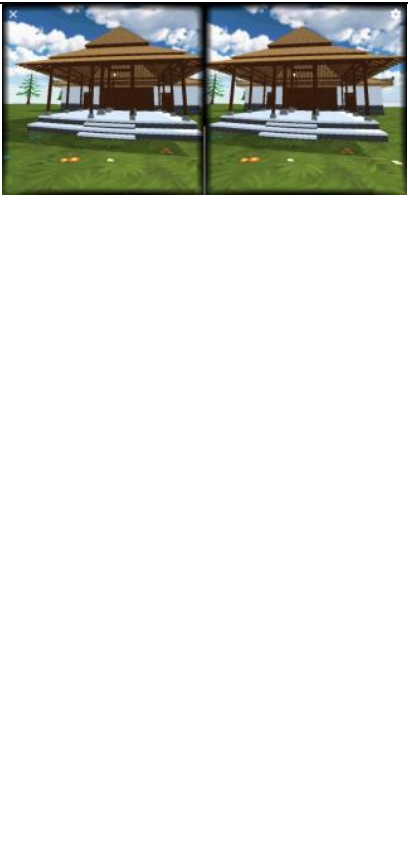 & $\begin{array}{l}\text { Pada awal } V R \\
\text { Tour di rumah } \\
\text { tradisional } \\
\text { Joglo } \\
\text { Yogyakarta } \\
\text { Indonesia, } \\
\text { pengguna } \\
\text { diberi tampilan } \\
\text { bangunan } \\
\text { rumah secara } \\
\text { keseluruhan. } \\
\text { Pada bagian } \\
\text { ini pengguna } \\
\text { dapat } \\
\text { mengitari } \\
\text { seluruh rumah } \\
\text { untuk melihat } \\
\text { bentuk rumah } \\
\text { secara utuh. }\end{array}$ \\
\hline 2. & (A) & $\begin{array}{l}\text { Pada seluruh } \\
\text { bagian } \\
\text { aplikasi, } \\
\text { terdapat } \\
\text { tombol } \\
\text { navigasi yang } \\
\text { jika kursor } \\
\text { diarahkan ke } \\
\text { salah satu } \\
\text { bagian akan } \\
\text { menunjukkan } \\
\text { fungsi } \\
\text { 'kembali ke } \\
\text { beranda', } \\
\text { 'melihat } \\
\text { keterangan } \\
\text { fungsi ruang } \\
\text { atau definisi } \\
\text { rumah', serta } \\
\text { menutup } \\
\text { seluruh tombol } \\
\text { navigasi. }\end{array}$ \\
\hline 3. & 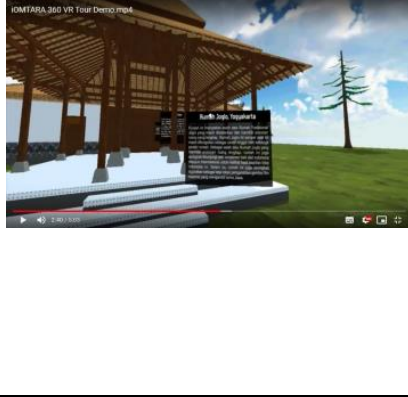 & $\begin{array}{l}\text { Di awal } V R \\
\text { Tour di bagian } \\
\text { luar rumah, } \\
\text { pengguna } \\
\text { dapat melihat } \\
\text { identitas dan } \\
\text { definisi rumah } \\
\text { tradisional } \\
\text { Joglo. }\end{array}$ \\
\hline
\end{tabular}



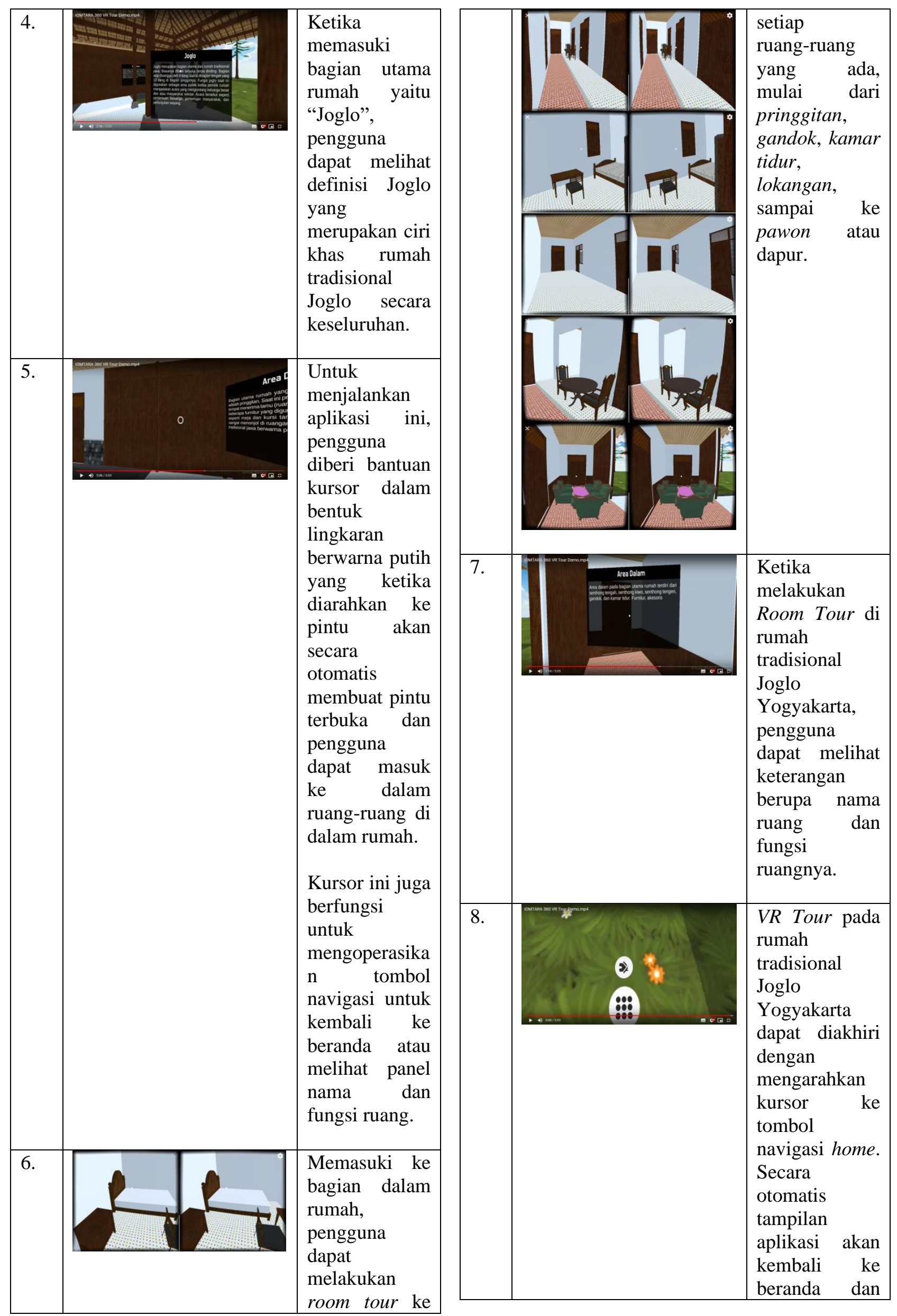


\begin{tabular}{|l|l|}
\hline & pengguna \\
& dapat \\
melanjutkan \\
VR Tour ke \\
rumah \\
& tradisional \\
& lainnya. \\
\hline
\end{tabular}

Tabel 2. Tampilan Panel Aplikasi iOMTARA tipe rumah tradisional Melaka Malaysia

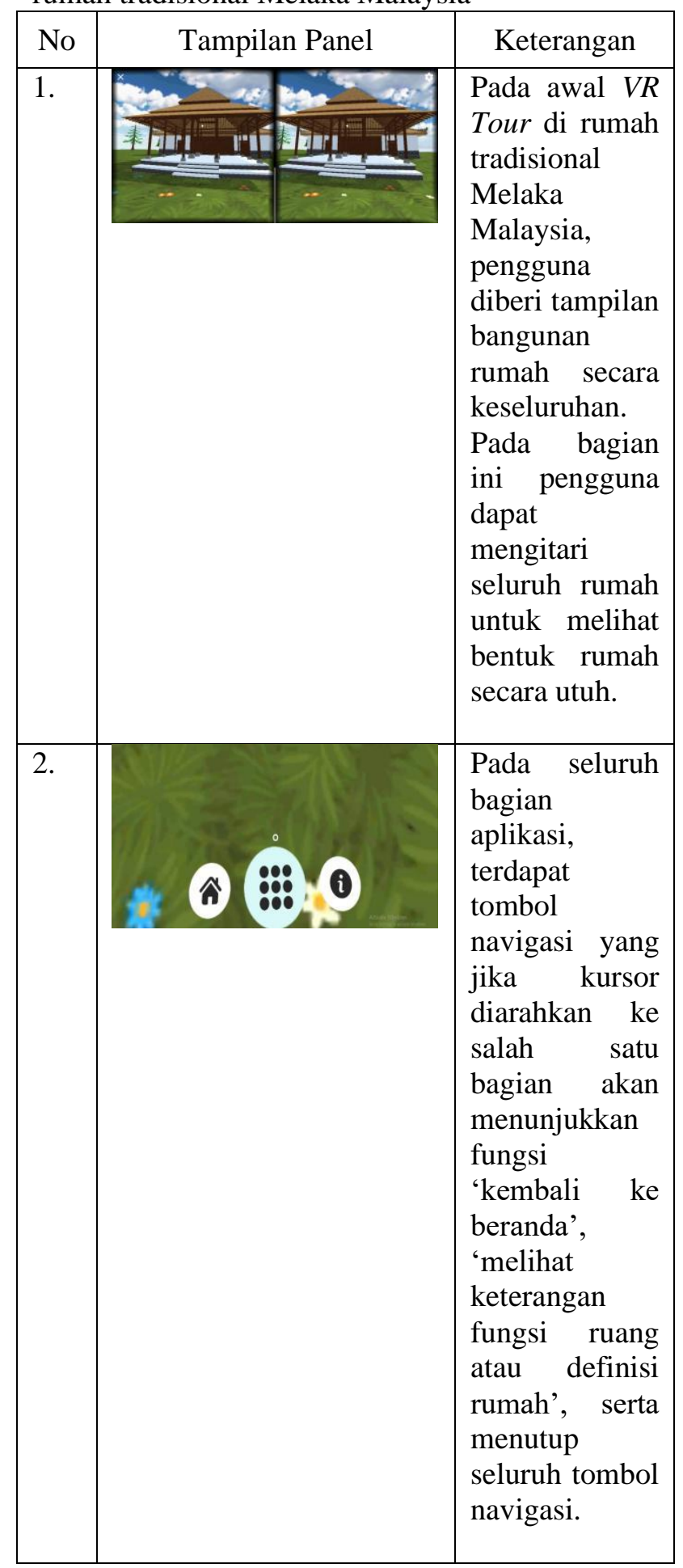

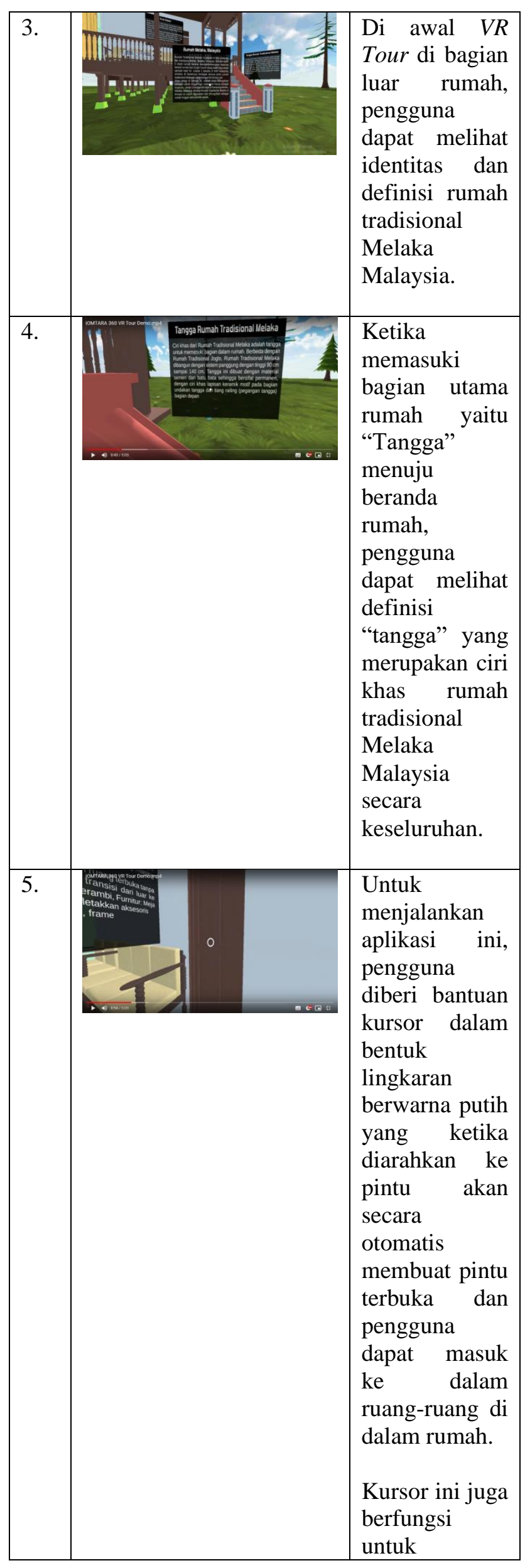




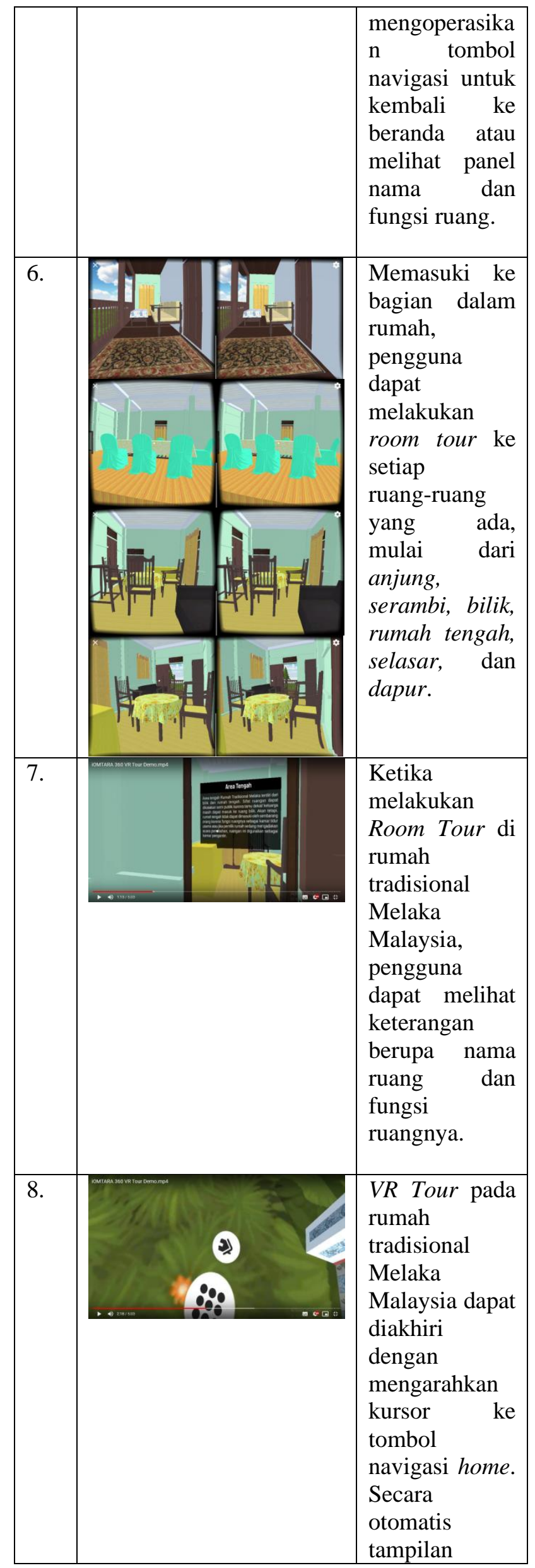

\begin{tabular}{|l|l|}
\hline & aplikasi akan \\
kembali ke \\
beranda dan \\
pengguna \\
dapat \\
melanjutkan \\
VR Tour ke \\
rumah \\
tradisional \\
lainnya. \\
\hline
\end{tabular}

Room Tour pada aplikasi iOMTARA ini dapat dijalankan dengan pengguna berjalan sesuai arah yang muncul di aplikasi dan $V R$ box. Untuk memudahkan pengguna, aplikasi ini dibuat juga dengan sistem berjalan otomatis ketika kursor diarahkan menunduk. Secara otomatis, pengguna akan merasa solah-olah berjalan maju ketika mengarahkan kursor ke bawah atau menunduk.

\section{SIMPULAN DAN SARAN Simpulan}

Media interaktif virtual reality tentang rumah tradisonal Nusantara, khususnyatentang rumah tradisonal Joglo Yogyakarta Indonesia dan rumah tradisional Melaka Malaysia sangatlah dibutuhkan. Hal ini karena Nusantara terdiri dari beberapa negara yang cakupannya cukup luas sehingga untuk mengunjungi objek wisata seperti rumah tinggal tradisional tersebut tidak bisa dilakukan dengan mudah atau terus menerus.Selain itu, meskipun masyarakat berkunjung langsung ke rumah tradisional tersebut, belum ada media informasi dalam bentuk 3D yang secara interaktif memberi informasi lengkap tentang rumah tradisional beserta ruang-ruang di dalamnya.

Media pengenalan pariwisata dalam bentuk aplikasi Room Tour yang menggunakan teknologi Virtual Reality, iOMTARA, merupakan tantangan dan potensi yang nyata bagi upaya pengenalan pariwisata Nusantara secara lebih mudah dan lebih luas kepada masyarakat. Aplikasi IOMTARA ditujukan bagi masyarakat umum yang berminat untuk mengenal dan berkunjung ke objek wisata nusantara dengan mudah dan optimal.

Aplikasi iOMTARA dapat dijalankan pada mobile phone dengan sistem operasi android jenis apapun. Pada penggunaannya dibantu dengan perangkat tambahan berupa VR Box. Berdasaerkan hal tersebut, dapat disimpulkan bahwa aplikasi ini mudah dijalankan karena tidak memerlukan peralatan khusu lainnya. 
Beberapa aspek yang mendasari pembuatan aplikasi iOMTARA dengan menggunakan teknologi virtual reality ini adalah target pengguna yang luas serta kemudahan penggunaannya. Berdasarkan hasil riset menunjukkan bahwa sebelumnya belum ada aplikasi serupa yang menawarkan tampilan virtual reality tentang objek wisata Nusantara. Oleh karena itu, aplikasi iOMTARA dibuat memberikan tampilan room tour yang menarik dengan teknologi virtual reality yang membuat penggunanya seolah-olah berada pada lingkungan yang nyata.

\section{Saran}

Setelah aplikasi ini dibuat dan diujicobakan, maka dapat disampaikan beberapa saran baik bagi pembaca maupun peneliti selanjutnya, antara lain:

1. Nusantara kaya akan objek wisata yang mungkin belum banyak dikenal oleh masyarakat luas, sehinggan aplikasi semacam ini masih perlu dikembangkan untuk objek-objek wisata lainnya di Indonesia.

2. Aplikasi iOMTARA masih memiliki kekurangan sehingga dapat lebih dikembangkan oleh peneliti selanjutnya. 


\section{Kepustakaan}

Sihite, B., Samopa, F., dan Sani, Nisfu A. 2013. "Pembuatan Aplikasi 3D Viewer Mobile dengan Menggunakan Teknologi Virtual Reality (Studi Kasus: Perobekan Bendera Belanda di Hotel Majapahit)", Jurnal Teknik POMITS, Vol.2, No.2, A-397-A400.

Prasetyo, A. N., Satoto, K.I., dan Martono, K. T. 2015. "Teknologi VRML untuk Media Promosi Mobil Berbasis Web", Jurnal Teknologi dan Sistem Komputer, Vol.3, No.1, PP. 132-141.

Solicitor C.R.E.C., A., Noventius, C., dan Bayu W., Aryo. 2018. "Media Interaktif Virtual Reality Biota Laut Indonesia sebagai Media Pembelajaran untuk Usia 11-13 Tahun", Seminar Nasional Seni dan Desain: Konvergensi Keilmuan Seni Rupa dan Desain Era 4.0”, FBS UNESA.

Djono, D., Utomo, Tri P., dan Subiyantoro, S. 2012. "Nilai Kearifan Lokal Rumah Tradisional Jawa", Jurnal Online Humaniora UGM, Vol. 24, No.3, PP. 269-278.

Subiyantoro, Slamet. 2010. "Transformasi Loro Blonyo - Rumah Joglo dalam Analisis Struktural", Jurnal Online Humaniora UGM Vol. 22, No.3, PP. 237-335.
Rasyidi, R. A. dan Amiuza, C. B. 2017. "Semiotika Arsitektur Rumah Adat Kudus Joglo Pencu", Jurnal Online Mahasiswa Jurusan Arsitektur Universitas Brawijaya Vol. 5, No.3, PP. 1-8.

Aziz, N. F., Jahi, J. Md., Arifin, K., dan Ujang, A. 2014. "Pengaruh Adat Resam, Kepercayaan, dan Kebudayaan terhadap Pembinaan Rumah Melayu Tradisional. International Journal of The Malay World and Civilisation (Formerly SARI)", Jurnal Antarabangsa Alam dan Tamadun Melayu (Imam), 2 (2). Pp. 105-111.

Talib, R. dan Sulieman, M. 2012. "Surveying on The Cultural Approaches for The Melaka Malay Houses", Procedia - Social and Behavioral Sciences Volume 65, 3 December 2012, Pages 511-516.

Arikunto, Suharsimi. 2010. "Prosedur Penelitian Suatu Pendekatan Praktik". Jakarta: PT. Rineka Cipta.

Sugiyono. 2011. "Metode Penelitian Kuantitatif Kualitatif dan R\&D”. Bandung: Alfabeta.

Bakar, Noor Shahira Abu., dkk. 2013. "Simbolisme dalam Pembinaan Rumah Tradisi Melaka". http://www.researchgate.net/. (Diakses pada 20 Desember 2018 Pukul 16.00 WIB). 